\title{
Neither Here Nor There: How to Fit in British Society in Kureishi's the Buddha of Suburbia and the Black Album?
}

\section{Özge Demir}

PhD. Candidate, Research Assistant, Department of English Language and Literature, Fatih University, Istanbul another_en@hotmail.com

\section{Doi:10.5901/ajis.2015.v4n3s1p689}

\begin{abstract}
"Diaspora" as a word dates back to ancient Greek, although its modern usage stems from its appearance in the translation of the Hebrew Bible into Greek by Jewish scholars. However, the Greek word diaspora is not related to migration; rather it connotes a religious meaning. In the second half of the 20th century, the meaning of the word diaspora broadened and began to be used for any ethnic, national, or religious community that is dispersed and settled in one or more countries. Yet, the issue of diaspora is not just restricted to the settlement of communities in other countries: diasporas are also about displacement, dislocation, and the maintaining of connections with a real or imagined homeland. This paper will analyse how Hanif Kureishi, as a diasporic writer, represents the struggle of first and second generation Pakistani immigrants to fit into British society during a chaotic time. Our analysis will be on Kureishi's The Buddha of Suburbia and The Black Album, which focus on the problems of the Indian diaspora through its main characters in 1970s and 80s Britain when racial tensions, prejudices, and class conflicts between the working class and the upper class take place in society. With the analysis of Kureishi's characters, both first and second generation, we will see how they experience in-betweenness and double-conciousness in the process of constructing a new identity. Moreover, we will present how they clash with both British society and their own diaspora while struggling to belong to two cultures at once.
\end{abstract}

Keywords: Post-colonial, diaspora, identity, double-conciousness, in-betweenness.

\section{Introduction}

As the mobility of the population has increased over the last fifty years due to political, economic, ethnic, and religious reasons, the term diaspora has begun to be used widely. When the history of the word is traced, we go back to ancient Greek, although its modern usage comes from the translation of the Hebrew Bible into Greek by Jewish scholars. However, the word diaspora does not refer to migration but rather it connotes a religious meaning, "the threat of dispersion facing the Hebrews if they failed to obey God's will" (Dufoix, 4). As time goes by, the term has undergone basic changes in its meaning. The Jews were at the centre again, but this time they experienced real dispersion due to the forced migration during the time of the Nazis. They dispersed around the world to escape genocide, and they formed diasporas wherever they went. Apart from the Jews, Afro-Americans are also associated with diasporas because of their dispersion to perform forced labour. Since these groups experienced forced migration on a huge scale, when people think of diaspora, they associate it directly with the Jewish and the Black/African diasporas.

However, in the second half of the twentieth century the meaning of word diaspora broadened and began to be used for any ethnic, national, or religious community that undergo dispersion and settle in one or more countries. Yet, the issue of diaspora is not restricted with the settlement of communities in other countries; it requires having some other factors that involve "maintenance of identity and community solidarity, which allows people to make contacts between groups and to organize activities aimed at preserving that identity; and finally, relations between the leaving state, the host state, and the diaspora itself..." (Dufoix, p. 21). As clearly stated above, diasporas are about the idea of displacement, dislocation and the maintenance of connections with a real or imagined homeland. Since diasporas are the communities that left their homelands to settle a new life in new places, they face serious problems in the host countries which affect them psychologically, culturally, socially and economically. While they try to preserve their original roots, they are exposed to the culture of the host land. The state of belonging to two cultures at the same time creates a person who is "in-between" as Homi Bhabha (1994) calls it. The diasporas and minority groups in host countries try to reconstruct a new identity despite racism, poverty, discrimination, etc. Especially, during the second half of the twentyfirst century, when many diasporas formed all over the world, a new field of literature emerged: diaspora literature which deals with issues concerning immigrants such as identity, displacement, dislocation, racism, double-consciousness, etc. 
Hanif Kureishi is one of the writers who explore the issues of diasporia literature in his works. As a child of a Pakistani father in the UK himself, he writes about the Indian diaspora in Great Britain. In this paper I will analyse how Hanif Kureishi as a diasporic writer represents the struggle of first, and second-generation Pakistani immigrants to fit into British society during a chaotic time through the novels The Buddha of Suburbia and The Black Album. While exploring these issues, I will focus on the factors that cause such problems for the members of the Indian diaspora and affect them psychologically, politically, and economically either as first-generation immigrants or the second-generation immigrants.

India has drawn attention as a major source of migration in the twenty-first century. The colonial history of India and the religious conflicts of the subcontinent created a country that offered no possibilities for its citizens to lead good lives. 1947, India's date of independence, coincided with its partition. Immediately after partition, approximately five million Hindus and Sikhs left Pakistan for India, and about six million Muslims moved into newly established Pakistan from India. Binod Khadria (2006) states that "this politically triggered exchange created very serious and long-term problems of refugee settlement and integration, the prospects of intra-Indian subcontinent migration became increasingly remote after India's independence" (p. 172). After World War II, many immigrants from India and other Asian countries, which were mainly poorly educated, came to the United Kingdom to meet increasing post-war labour shortages. However, not only those unemployed, but also students who wanted to get a better education came to the UK. Upon the arrival of these immigrants, the country turned out to be multicultural, multiracial society in which the conflict of white and black appeared. Apart from the harsh attitude of England's citizens toward Indian diaspora, these immigrants faced internal conflicts of identity and personality. Hanif Kureishi is a member of the Indian diaspora in UK, born to a Pakistani father and an English mother. His father belonged to a relatively rich, upper-class family in Madras, and he came to England to study law. Although he did not complete his studies, he stayed in England and worked at the Pakistani Embassy while other members of his family moved to Pakistan after the partition. His father experienced dispersion even in his homeland. While witnessing changes in the UK's social structure, Kureishi wrote many novels, short stories, film scripts, and dramas to represent the struggles of both generations.

The Buddha of Suburbia (1990), Hanif Kureishi's first novel, is a semi-autobiographical book focused on the search of the protagonist Karim's social and sexual identity in 1970s Britain. The novel consists of two parts - In the Suburbs and In the City - which show the social transformation of characters throughout the novel. Kureishi, who expresses that "We are all mixed-race now," represents it in his protagonist Karim, who is the son of an Indian Muslim immigrant and an ordinary Anglo-Saxon British woman in 1970s Britain. Karim undergoes many difficulties while constructing his immigrant identity in the face of discrimination against 'colored' people. The Buddha of Suburbia is like a mirror since it reflects life in 1970s Britain, where racial tensions, prejudices and class conflicts between working class and upper class in the society take place. While we're reading the novel, it feels like Kureishi is taking us on a tour in 1970s and 1980s Britain with all its complicated social and political life.

Around the 70s' and 80s', the time when the number of immigrants from the Indian subcontinent increased, "British government was concerned with how best to limit Asian (and black) settlements without tarnishing the country's liberal image" (Khadria, 174). As Kureishi shows in the novel, there was a great political debate and rivalry between Conservatives and the Labour Party. However, when the Conservatives had the power, and Margaret Thatcher won the elections, a new era started for Britain. Thatcherism was effective in every field of government although it is basically associated with economic changes that led many people to unemployment, and forced people to pay unfair taxes. Thatcher also had statements on race, national identity, the family, multiculturalism and morality. Sezer (2010) quotes from Green that for Thatcher and her supporters to be British was defined by narrow boundaries of geographical origin and kinship. (p. 145) Thatcher never wanted to accept those immigrants as Englishmen, even the second generation who were born into the UK. For her the notion of Britishness was static although according to famous critic Stuart Hall, cultural identity is a slippery term since "it is a matter of becoming rather than being" (p. 225). Apart from Thatcher, Enoch Powell, who was an important politician of the Conservative Party, expressed a strong sense of nationalism and even racism in his famous speech Rivers of Blood. This nationalist party did not want immigrants in their country and had a strict policy on immigration, and it found support especially among working class. So, there were aroused organisations against immigration and that supported racism. The National Front is an organisation that protested against immigration and fought against the inclusion of immigrants in British society. Especially the white, middle-class UK citizens were against the new-comers of the country.

The stimulation to exclude Asian immigrants prevented the UK from being a multiracial and multicultural society. Racism in the country was an outgrowth of economic problems such as unemployment, poverty, and housing problems. Roy Porter expresses that "the importing of low-waged immigrant labour greatly incited racial hatred of the white working class towards the immigrants" (qtd. in Su, 251). Kureishi emphasizes how his characters are exposed to racist attacks in 
the suburbs of London. While the protagonist Karim is walking along the street with his friend Jamila, newly renamed Jammie, a British man shouts at them "Eat the shit, Pakis" (53). Whereupon, Jamila tells him about her country's oppressed people who face violence in this racist country. Apart from verbal attacks, there were also physical attacks on various ethnic groups, especially against Asians. Karim describes these groups who attack immigrants:

At night, they roamed the streets, beating Asians and shoving shit and burning rags through their letter-boxes. Frequently, the mean, white, hating faces had public meetings and Union Jacks were paraded through the streets, protected by the police. There was no evidence that these people would go away - no evidence that their power would diminish rather than increase. The lives of Anwar and Jeeta and Jamila were pervaded by fear of violence. I'm sure it was something they thought about everyday Jeeta kept buckets of water around her bed in case the shop was firebombed in the night. Many of Jamila's attitudes were inspired by the possibility that a white group might kill one of us one day. (p. 56)

The fear of the family increases as these racist groups scrawl graffiti on the wall of their house's, and the threat becomes reality when a pig's head is thrown through the shop as they are sitting in it, and they are injured in this event. Later on, Jamila's Indian husband Changez is attacked by an extremist group. Everything happens suddenly: "It was a typical South London evening - silent, dark, cold, foggy, damp - when this gang jumped out on Changez and called him a Paki, not realizing he was Indian. They planted their feet all over him and started to carve the initials of the National Front into his stomach with a razor blade" (p. 224). The National Front threatens the lives of Asian people and attacks their shops in order to cut their income. Karim himself is affected by the racist attitude of schoolboys, and he recalls how they treated him because of his colour:

I was sick too of being affectionately called Shitface and Curryface, and of coming home covered in spit and snot and chalk and wood-shavings. We did a lot of woodwork at our school, and other kids liked to lock me and my friends in the store room and have us chant 'Manchester United, Manchester United, we are the boot boys' as they held chisels to our throats and cut off our shoelaces. We did a lot of woodwork at the school because they didn't think we could deal with books. (p. 63)

This paragraph is important since it clarifies the book as not just mere fiction but as autobiography. In an interview Kureishi expressed how he experienced more or less the same things: "I remember going to school and being racially abused. I remember my mother going to the school to complain. It was as if she hadn't realized the consequences of marrying an Indian man. These consequences only worked themselves out later on: suddenly you've got this boy and everybody spits on him and you are completely devastated" (Kumar, 2001, p. 122). The characters express what British people think about themselves in a merciless way while they try to construct a new identity based on their Indian roots and British culture: "The thing was, we were supposed to be English, but to the English we were always wogs and nigs and Pakis and the rest of it" (p. 53). Karim realizes this truth once again when he is scolded by the father of his girlfriend, Helen. The father is direct and harsh in his speech: "'You can't see my daughter again, said Hairy Back. She doesn't go out with boys. Or with wogs... However many niggers there are, we don't like it. We're with Enoch. If you put one of your black 'ands near my daughter, I will smash it with a 'ammer! With a 'ammer! Hairy Back slammed the front door" (p. 40). For some immigrants, racism and discrimination is so unbearable that they even decide to end their lives. The exlover of Eleanor, who is Karim's upper-class, white girl-friend, committed suicide because of these racist attitudes toward him:

Gene was a young West Indian actor. He was very talented and sensitive....he was better than a lot of people. So he was very angry about a lot of things. The police were always picking him up and giving him a going over. Taxis drove straight past him. People said there were no free tables in empty restaurants. He lived in a bad world in nice old England. One day when he didn't get into one of the bigger theatre companies, he couldn't take any more. He just freaked out. He took an overdose. Eleanor was working. She came home and found him dead. (p. 201)

When the social and economic state of the Indian diaspora are examined, we see that they're more or less interconnected because the quality of social life of an individual is directly proportional to his income. Since Indian immigrants are mainly composed of unskilled workers, they work in low-wage jobs with long hours of shift. Karim's father, Haroon, is a "badly paid and insignificant" Civil Service clerk in the British Government (p. 7), and his mother works as a sale assistant in a shoe store. Rita Felski states that "lower-middle-classness is still a 'cage of umbrellas and steely regularity' (BS, 26), marked by respectability, rigidity, and gray routine" (p. 37). For the lower-middle-class, social life did not exist, as is clear from the life of Haroon: "No one went out, there was nowhere to go, and Dad never socialised with anyone from the office. They too fled London as quickly as they could after work. Mum and Dad went to the pictures 
maybe once a year, and Dad always fall asleep; once they went to the theatre to see West Side Story" (p. 46). Karim feels trapped in this boring life of his parents and wants to escape his petit bourgeois origins to achieve social mobility; therefore, he wants to get a job among the artists and upper-middle-class people.

The most striking side-effect of immigration is seen on the psychology of individuals, or more collectively, on the whole diaspora. When they migrate from their home country, full of their traditions, cultures, and beliefs, their cultural system clashes with the host country's system. The one who succeeds to fit into the society gains a hybrid identity, but the others become misfits in the society, trapped between two cultures and belonging nowhere. These 'in-between' individuals suffer from exclusion, displacement, alienation, and identity conflict. As a result of this exclusion, they either reject British culture, or cling to fanaticism and radicalism, or they seek consolation in drugs, raves, and sex (Töngür, p. 91). Clearly, diaspora identities are dynamic, and in constant change. For Hall, "they constantly produce and reproduce themselves, through transformation and change. It belongs to the future as much as to the past. It is not something that already exists, transcending place, time, history, and culture" (p. 235). In order to fit into the British society, the characters use the flexible aspect of identity and try to Westernise themselves. So they are trapped between their Indian or Pakistani identity and their newly gained British identity. For example, Karim says, "My brother Amar, four years younger than me, called himself Allie to avoid racial trouble" (p. 19). Another example of this renaming is Karim's father: "Ted and Jean never called Dad by his Indian name, Haroon Amir. He was always 'Harry' to them, and they spoke of him as Harry to other people. It was bad enough his being an Indian in the first place, without having an awkward name too" (p. 33). Some of the characters try to be English by casting off their national clothes and dressing in a modern and Western way. However, there is a striking fact that they are scorned by their fellow countrymen if they do not appear British. They see it as something to be ashamed of and accuse those who cannot fit into the British society. For example, Changez feels a kind of disgust when he sees traditional Asian men in England. Yet there is an irony in Changez's situation because although he feels British, he is not seen and accepted by the natives, they do not even see him an Indian but instead yell at him as a Paki when the nationalist gang attacks him for nothing.

Look at that low-class person, he'd say in a loud voice, stopping and pointing out one of his fellow countrymen - perhaps a waiter hurrying to work or an old man ambling to the day centre, or especially a group of Sikhs going to visit their accountant. 'Yes, have souls, but the reason there is this bad racialism is because they are so dirty, so rough-looking, so bad-mannered. And they are wearing such strange clothes for the Englishman, turbans and all. To be accepted they must take up the English ways and forget their filthy villages! They must decide to be either here or there. Look how much here I am! (p. 210)

In this ugly political atmosphere, British citizens are stimulated to exclude immigrants based on race. Politicians play a great part in dissociating the society with their racist discourses. Although the immigrants want to integrate, they are separated based on their differences. Samir Dayal (1996) refers to this discrimination saying that: "Instead of marking an achieved pluralized space and time guaranteeing an equal political address within the nation-space, the model immigrant category is sometimes ironically constructed as precisely a divisive and subordinating condition for "belonging" (p. 50).

There are significant differences between the two generations of immigrants in the UK. While the first generation fails to learn British habits and culture or find a place in society, the second generation faces the struggle of belonging to two cultures. The first generation comes with its own cultural norms and they have difficulty in adapting to the country; so they turn into alienated misfits in the society. Experiencing discrimination in all parts of daily life has a big part in their disintegration into society. Karim tells his father's discomfort: "'The whites will never promote us', Dad said. 'Not an Indian while a white man left on the earth. You don't have to deal with them - they still think they have an Empire when they don't have two pennies to rub together'" (p. 27). Haroon, Karim's father is among the first generation of immigrants, so for him it is not easy to lose its Indian identity and harmonise with British culture. Since he does not belong to this country, he lacks orientation in the streets where he has lived nearby for almost two decades. Karim complains about this situation: "Dad had been in Britain since 1950 -over twenty years- and for fifteen of those years he'd lived in the South London suburbs. Yet still he stumbled around the place like an Indian just off the boat, and asked questions like, "Is Dover in Kent?" (p. 7). Haroon turns to Oriental philosophies and practices in search of his identity, but he cannot carry on with it since white people see it as rubbish. He even exaggerates his Indian accent by hissing his s's. In addition, he neither sticks to the rules of his religion, Islam, nor loses himself fully in the extreme pleasures of life. Haroon tries to balance his life between two different cultures; one time they stick to their traditions, but on other time they totally forget about it and enjoy the pleasures of the new culture. Dayal (1996) explains this condition: "... diasporics may position themselves as resisting assimilation, liminally situated on the borders or fault lines, alive to the play of 
contradiction and to the unregulated possibilities of such a positioning" (p. 52). Like Haroon, his brother Anwar lives in contradictions; one day he attends prayers in the mosque, but when he comes home, he drinks alcohol and eats pork.

Other aspect of diasporas is that the immigrants have a goal of returning to their idealised and imagined homelands (Dufoix, 2008, p. 22). Although the characters do not clearly express this in The Buddha of Suburbia, there is a longing for the home country, and they want to return to their homelands in some way, maybe an internal return to their imagined homelands. This does occur in the second generation of diasporas since they are not born into their native land so they may not feel the attachment as their fathers did. The first-generation immigrants feel a kind of linkage to their countries and cultures. Karim observes his father and Uncle Anwar and thinks that "Now, as they aged and seemed settled here, Anwar and Dad appeared to be returning internally to India, or at least be resisting to English here" (p. 64). And Karim's observation is justified when his father expresses his feelings about his home country: "We old Indians come to like this England less and less and we returned to an imagined India" (p. 74). Anwar also says that "I want to go home now ... I've had enough of this damn place" (p. 172). Through the end of the book, Haroon confesses that "I have lived in the West for most of my life, and I will die here, yet I remain to all intents and purposes an Indian man. I'll never be anything but an Indian" (p. 263). It's clear that even the first-generation immigrants experience in-betweenness. They are not completely Asian anymore, they are neither British, though; so they feel trapped between two cultures all the time.

Although the older generation feels a kind of belonging to their homeland, the new generation is somewhat trapped in this society, and it is indicated in the novel by a British man as "belonging nowhere" (p. 141). Hence, whatever the characters do to escape their origins, they come across their double-identity. The second-generation has ancestral customs with them which are mostly not practiced, yet they are born into and grow up in British culture. Our protagonist Karim suffers from the same problem, as the second-generation of immigrants, who were born in the UK: "I am an Englishman born and bred, almost. I am often considered to be a funny kind of Englishman, a new breed as it were, having emerged from two old histories. But I don't care - Englishman I am (though not proud of it), from the South London suburbs and going somewhere. Perhaps it is the odd mixture of continents and blood, of here and there, of belonging and not, that makes me restless and easily bored" (p. 3). Even the opening lines of The Buddha of Suburbia show the main issue of the novel. Karim also denies his Indian identity because he sees it inferior to the Britishness. In the funeral of his Uncle Anwar, he muses:

But I did feel, looking at these strange creatures now — the Indians — that in some way these were my people, and that l'd spent my life denying or avoiding that fact. I felt ashamed and incomplete at the same time, as if half of me were missing, and as if l'd been colluding with my enemies, those whites who wanted Indians to be like them. Partly I blamed Dad for this. After all, like Anwar, for most of his life he'd never shown any interest in going back to India. He was always honest about this: He preferred England in every way. Things worked; it wasn't hot; you didn't see terrible things on the street that you could do nothing about. He wasn't proud of his past, but he wasn't unproud of it either; it just existed, and there wasn't any point in fetishizing it, as some liberals and Asian radicals liked to do. So if I wanted to additional personality bonus of an Indian past, I would have to create it. (p. 212)

Although Karim does not want to remember his hybrid condition and he just wants to focus on his own life, on how to develop himself and start the career he wants, people around him wonder about this state of solidarity led by the exclusion of two cultures. Mr. Shadwell sees him as a half-caste in England and he says: "That must be complicated for you to accept - belonging nowhere, wanted nowhere. Racism. Do you find it difficult? Please tell me" (p. 141). However hard he tries to forget his burden of being Asian, he has to carry it everywhere. On his way to create a new self, he decides to be an actor and joins a theatre group. They will play The Jungle Book by Kipling, who is well-known for his colonial discourse. Worse still, he is asked to play the role of Mowgli since he is dark-skinned, small and wiry like him. In order to succeed, Karim accepts the role but he feels miserable when his dad and cousin come to watch him. Since Karim exaggerates the accent and the clichés about the Indians, his parents freak out and accuse him of playing in a neo-fascist play. Haroon goes further: "The bloody fucker Mr. Kipling pretending to withy he knew something about India! And an awful performance by my boy looking like a Black and White Minstrel!" (p. 157). Kureishi portrays a postcolonial Bildungsroman in Karim's attempts to find himself, and create an identity that is barely his. In his struggle to create his own identity, he has ups and downs but he does not care about the others so that in addition to his Indian identity, he constructs a bisexual identity. He is attracted to his step-mother's son, Charlie. With his second identity based on sex, he defies the British rules once more since Thatcher is homophobic and they even made a law against this kind of relationship. However, Karim is not a real Indian either; his mother expresses this: "But you're not an Indian. You've never been to India. You'd get diarrhoea the minute you stepped off that plane, I know you would" (p. 232). So, it is obvious that Karim is a hybrid character who is in-between of two different cultures. He neither completely clings to an 
Indian identity nor the British. He has a double-consciousness: on the one side he represents Indian values while he sticks to the host country's values. He is never fully Indian or British. As Homi Bhabba (1994) states: "identity is never a priori, nor a finished product; it is only ever a problematic process of access to an image of totality" (p. 73).

Published five years later than The Buddha of Suburbia, The Black Album (1995) is Kureishi's second novel which explores crucial issues such as Islamic radicalism, ecstasy, censorship, and Prince in late 1980s London, as well as religious and cultural clashes between Britain and its immigrants. The novel originates from the controversies based on the imposition of the fatwa on Salman Rushdie by Ayatullah Khomeini in 1989. The rise of Islamic radicalism during the Rushdie affair attracts Kureishi's attention and he puts this controversial topic in the centre of The Black Album with the criticism of fascist manners of both racists and anti-racists in multiracial British society in the late 1980s. In contrast to The Buddha of Suburbia, as the title of the novel refers, this book is a means to celebrate the multicultural, multiracial British society in the late twentieth century. The Black Album is the name of the American musician, Prince's lost album, available only illegally, as its release was cancelled in 1987. Prince is an important figure in the celebration of diversity in race, culture, and gender since: "he's half-black and half-white, half man, half woman, half size, feminine but macho, too" (p. 25). Although UK has undergone some changes in its cultural structure since the 1980s, racism is still strong as understood from Shahid's experiences:

Everywhere I went I was the only dark-skinned person. How did this make people see me? I began to be scared of going into certain places. I didn't know what they were thinking. I was convinced they were full of sneering and disgust and hatred. And if they were pleasant, I imagined they were hypocrites. I became paranoid. I couldn't go out. I knew I was confused and ... fucked-up. I didn't know what to do. (p. 10)

Like Karim, the protagonist of The Black Album, Shahid, is also exposed to racism at school by his classmates who call him: "Paki Wog Fuck Off Home," and "Paki, Paki, Paki, Out, Out, Out!" (p. 72) The streets and homes still do not seem safe for Pakistani immigrants. Shahid and his extremist group members find themselves in the middle of a racist attack. When they are protecting a mother and her daughter in their home, a British woman comes: "Paki! Paki! Paki!' she screamed. Her body had become an arched limb of hatred with a livid opening at the tip, spewing curses. 'You stolen our jobs! Taken our housing! Paki got everything! Give it back and go back home!" (p. 139). Again, the problem of racism is linked to the economic condition of the British working-class. They're envious of Asian immigrants who came and got the jobs that they thought inferior, but now they accuse these people for their bad economic condition. Shahid sees tension in the society and he expresses his fears: "We're third-class citizens, even lower than the white working class. Racist violence is getting worse! Papa thought it would stop, that we'd be accepted here as English. We haven't been! We're not equal! It's gonna be like America. However far we go, we'll always be underneath!" (p. 209). Apart from Shahid, Zulma, sister-in-law of Shahid although she was an intelligent and upper-class woman, still has no place in this society since "to them she'd always be a Paki, and liable to be patronized" (p. 87).

As in the 1970s, the racist attacks still carry on despite the changes in government. There are still oral and physical attacks on Asians, Blacks or any kind of "alien". Since Muslim women look different in their hijab, they are generally attacked orally. Tahira expresses this trouble: "We're constantly mocked and reviled, as if we were the dirty ones. Yesterday a man on the street said, this is England, not Dubai, and tried to rip my scarf off" (p. 105). Shahid and his radical friends help Asian families who seek protection against the attacks of racist groups. They go to the flat of a Bengali family with cricket bats, clubs, knuckle-dusters and carving knives, and they take action against the racists with an enthusiasm of jihad. They have a good reason to defend by the way since

The family had been harried - stared at, spat on, called 'Paki scum' - for months, and finally attacked. The husband had been smashed over the head with a bottle and taken to hospital. The wife had been punched. Light matches had been pushed through the letter-box. At all hours, the bell had been rung, and the culprits said they would return to slaughter the children. Chad reckoned the aggressors weren't the neo-fascist skinheads. It was beneath the strutting lads to get involved lowly harassment. These hooligans were twelve and thirteen years old. (p. 90)

As the protagonist of The Buddha of Suburbia, Shahid suffers from the identity crises of second-generation immigrants. Shahid is in a desperate need of an identity. He thinks that without an identity, the individual cannot succeed. Kureishi explains this need as: "Now, though, Shahid was afraid his ignorance would place him in no man's land. These days everybody was insisting on their identity, coming out as a man, woman, gay, black, Jew - brandishing whichever features they could claim, as if without a tag they wouldn' be human" (p. 92). He's literally torn between his Pakistani, Muslim identity and the British identity. The idea of in-betweenness is apparent in the hybrid identity of Shahid and other Indian characters in the novel. He wants to be both with his fundamentalist friends and his liberal girlfriend Deedee, who 
lives in the extremities. While one offers strong religious beliefs and close ties with his Pakistani fellows, the other offers a life with no stress and with drugs, alcohol, and sex. Kaleta claims that "Shahid vacillates between belief and worship, between fiction and reality, between intellectual pleasures and simple pleasures of the body, between cultural assimilation and cultural identity" (qtd. in Töngür, 98). Step by step he breaks his bonds with his fellows and turns to the side of Deedee. Shahid tries to fill gaps in his identity by getting rid of the sense of exclusion in British society. Considering his identity, Shahid's mind is a "tabula rasa," he does not know Pakistani culture, and he is not sure about British culture and not sure to adopt it, though. He experiences both sides with the help of side-characters. His girlfriend, who is older than him symbolizes the Western way of life with every possibility. He indulges in sweet dreams when he is thinking of Deedee but then he feels a kind of resentment. Kureishi describes the complicated feelings of Shahid:

But instead of bathing in the warm memory of the love they'd made and the pleasures she'd introduced him to, which they could delectably repeat and extend into the future, he became aware of a bitter, disillusioned feeling. How he'd been drowning in his senses in the past hours! What illusions he'd been subjected to! What torrents of drug-inspired debris he had allowed to stream through his head! What banal fantasies he believed were visions! (p. 130).

On the other hand, there are his Muslim friends who totally embrace Muslim identity and live their lives as Islam requires. The way they dress, pray, and act is merely in order to separate themselves from other groups. Now they do what the British do to them, they stress their differences and want to be known as much. For example, Chad insists that Shahid wear shalwar and go to mosque like that. Although he feels strange in this outfit, he also feels integrated. As the days go by, Shahid feels the urge to make a decision between the two cultures. The tension increases in London due to Salman Rushdie's book Satanic Verses that attacks the Prophet Mohamed. As in many parts of the world, there are demonstrations in London, too. Although Shahid loves the book, he has to attend the demonstration unwillingly and burn the book. Although they are not in contact anymore with Deedee, Shahid undergoes a breaking point when he sees Deedee with three policemen who disrupt the crowd. Apart from book burning, the city is in flames due to the two bombings in the tube stations.

In the formation of Shahid's identity, the attitude of his fundamental friends is really important since when Shahid transcribes Riaz's poems, he plays with words and gets away with it, then Chad says he is revealing his dirty mind and sexual fantasies. He is excluded from the group because they think that he has betrayed them. After the fight between Hat and Shahid, Chad is after him. They follow him to Deedee's house. They beat Shahid and even try set fire to the house; luckily Chili saves his brother. In the end, Shahid decides and says to Deedee: "I'm sick of being bossed around, whether by Riaz or Chad or God himself. I can't be limited when there is everything to learn and read and discover. And you..." (p. 272). As Shahid hears the news of Chad's getting injured in the book-burning and attacked in the shop events, he feels a kind of relief to choose the right part for him.

Chili, the brother of Shahid, is another character who is trapped between two cultures. In contrast to his brother's religious attempts, Chili remains a hedonist. For him, life consists of expensive cars, brand-name clothes, and women, although he is married to a Pakistani woman, Zulma. With his Westernised appearance, Chili seems to have adopted British society: "In Chili's hands were his car keys, Ray-Bans, and Marlboros, without which he wouldn't leave his bathroom. Chili drank only black coffee and neat Jack Daniel's; his suits were Boss, his underwear Calvin Klein, his actor Pacino" (p. 38). Although he appears Westernised, he still likes listening to Pakistani qawali singer Nasrut Fatah Ali Khan.

Chad, or as his real name Trevor Buss, is the most alienated and excluded character in the novel. He's the extremist type of boy who is hostile toward Western values. He does not belong to anywhere, he claims that "I am homeless ... I have no country ... I don't know what it is to feel like a normal citizen" (p. 108). Once he wanted to get closer to his origins, but he felt that it was impossible:

When he got to be a teenager he saw he had no roots, no connections with Pakistan, couldn't even speak the language. So he went to Urdu classes. But when he tried asking for the salt in Southall everyone fell about at his accent. In England white people looked at him as if he were going to steal their car or their handbag, particularly as he dressed like a ragamuffin. But in Pakistan they looked at him even more strangely. Why should he be able to fit into a Third World theocracy? (p. 107)

Since he was unable to integrate into Pakistani culture or British, Chad decides to construct a new identity that is based on religion. In the mosque, where all borders are removed, he feels complete. The sense of exclusion caused Chad to be a fundamentalist. He could only fill this gap by having a radical Muslim identity. He just wants to be defined as a Muslim, and he even changes his name to Muhammed Shahabuddin Ali-Shah. 
In contrast to The Buddha of Suburbia, The Black Album does not focus on generational differences. The reader is shown a glimpse of the lives of Shahid's mother and father, through which we learn that his father was working until his arse ached. Since his mother's family was respected in Karachi, she even ignored the bruises, cuts, and all kinds of abuse against them as a way of escaping the reality of Britain. It is clear that the first-generation is more conservative in their ways and they do not bother to create a new identity as the second generation do. Of course, the changing face of Britain is effective in the formation the second-generation's identity. Although many of them cannot succeed in forming a new identity that is a mixture of the host and home cultures, Shahid finally reaches his goal and chooses the life he wants to live.

In conclusion, Kureishi, in both of his books, clearly portrays life in 1970s and 1980s England, where social tension is highlighted due to the immigrant population that is seen as a threat since as Anne Marie Smith states, "Subversive immigrants, it was feared, would "congregate together" in areas that might soon become "English Harlems" ( p. 214). He brilliantly shows the colourful British culture as in total contradiction to the Asian traditions and culture either in the first or in the second generation. As a diasporic writer, he presents the identity crisis that the characters undergo in order to fit into the society where they live. In their struggle to create an identity, trapped between their home and host country, they experience dislocation and displacement which results in in-betweenness and double-consciousness in the characters. Both Karim and Shahid are forced to create their own identity out of two cultures. In the process, they face serious problems such as verbal and physical attacks in a racist atmosphere. However, in the end they succeed to create themselves despite all their shortenings.

\section{References}

Bhabba, H. (1994). The Location of Culture. NewYork, USA: Routledge.

Dayal, S. (1996). Diaspora and Double Consciousness. The Journal of the Midwest Modern Language Association. 29.1, 46-62.

Dufoix, S. ( 2008). Diasporas. (W. Rodarmor, Trans.) Berkeley, USA: University of California Press.

Felski, R. (2000). Nothing to Declare: Identity, Shame, and the Lower Middle Class. PMLA. 115.1, 33-45.

Hall, S. (1990). Cultural Identity and Diaspora. In Jonathan Rutherford (Ed.) Identity: Community, Culture, Difference (1st ed. pp. 222237) London, Great Britain: Billing and Sons Worcester Press.

Khadria, B. (2006). Migration between India and the UK. Public Policy Research. 13.3, 172-184.

Kidd, J. (2010). Hanif Kureishi: We're all mixed-race now. The Independent, 28 February Retrieved from http://www.independent. co.uk/arts-entertainment/books/features/hanif-kureishi-were-all-mixedrace-now-1909507.html, accessed 5 May 2012.

Kumar A., \& Kureishi, H. (2001). A Bang and a Whimper. Transition. 88, 114-131.

Kureishi, H. (2010). The Black Album. London, United Kingdom: Faber and Faber.

Kureshi, H. (1999). The Buddha of Suburbia. London, United Kingdom: Faber and Faber.

Sezer, S. (2010). Redefining Britishness in The Buddha of Suburbia by Hanif Kureishi. Hanif Kureishi and His Work. (1st ed. pp 145-151) Ankara, Türkiye: Sözkesen Press.

Su, J. (2010). Reconfiguring the Past: Cartographies of Post-Imperial London in The Satanic Verses and The Buddha of Suburbia. Concentric: Literary and Cultural Studies. 3.6, 243-263.

Töngür A. N. (2009). Hybrid or Misfit? The Brown Man's Burden: Hanif Kureishi's The Buddha of Suburbia and The Black Album. 17th Metu British Novelists Conference Hanif Kureishi and His Work (pp. 91-102). Orta Doğu Teknik Üniversitesi, Ankara, Turkey.

Waters, C. (1996). The Pink and the Black [Review of the book New Right Discourse on Race and Sexuality: Britain, 1968-1990, by A. M. Smith]. Transition, 69, 210-221. 